J. Pijar MIPA, Vol. VI No.1, Maret : 13 - 17

ISSN 1907-1744

\title{
SUHU INKUBASI MEMPENGARUHI LEVEL EKSPRESI SOX9 PADA TAHAP AWAL PERKEMBANGAN GONAD EMBRIO Chelonia mydas (PENYU HIJAU)
}

\author{
Syamsul Bahri \\ Program Studi Pendidikan Biologi, Jurusan PMIPA FKIP Universitas Mataram \\ Jl. Majapahit 62 Mataram, 83125
}

\begin{abstract}
Abstrak : Salah faktor penting yang diduga terlibat dalam penentuan jenis kelamin hewan TSD adalah Sox9. Protein ini berperan dalam cascade determinasi seks. Ketika kadar protein Sox9 mencapai nilai ambang tertentu maka gonad indiferen akan memasuki jalur diferensiasi testis. Penelitian ini bertujuan mengamati level ekspresi gen tersebut pada tahap awal perkembangan gonad Chelonia mydas yang termasuk dalam kelompok hewan TSD. Sebagian telur diinkubasi pada suhu $31 \pm 1^{\circ} \mathrm{C}$ untuk menghasilkan $100 \%$ individu betina (Suhu Feminisasi, SF), sedangkan telur lainnya diinkubasi pada suhu $26 \pm 1{ }^{\circ} \mathrm{C}$ untuk menghasilkan $100 \%$ individu jantan (Suhu Maskulinisasi, SM). Pengamatan dilakukan pada level mRNA yang terekspresi sejak periode pra TSP hingga TSP akhir. Level ekspresi Sf1 kompleks adrenal-gonad-ginjal dari embrio tahap perkembangan 12, 14, 16 (pra TSP), 17, 19 dan 22 (TSP) yang diinkubasi pada suhu feminisasi $\left(31 \pm 1^{\circ} \mathrm{C}\right)$ atau suhu maskulinisasi $\left(26 \pm 1^{\circ} \mathrm{C}\right)$ dideteksi dengan menggunakan metode $R T-P C R$. Sebagai pembanding digunakan housekeeping gene â-actin. Hasil amplifikasi di elektroforesis pada Agarose-TAE kemudian di foto dengan kamera digital. Densitas larik DNA yang terbentuk pada masing-masing tahap perkembangan embrio dan perlakuan ditentukan dengan menggunakan software ScionImage. Rata-rata bacaan pada setiap larik di visualisasi dalam bentuk diagram garis. Hasil RT-PCR menunjukkan bahwa suhu inkubasi mempengaruhi level ekspresi Sox9. Level ekspresi Sox9 tampak lebih tinggi pada embrio yang diinkubasi pada SM $\left(26 \pm 1^{\circ} \mathrm{C}\right)$ dibandingkan dengan level ekspresi Sox 9 embrio yang diinkubasi pada SF $\left(31 \pm 1^{\circ} \mathrm{C}\right)$. Perbedaan level ekspresi tersebut terlihat sejak tahap pra TSP tengah hingga TSP tengah. Perbedaan terbesar terlihat menjelang embrio memasuki tahap TSP. Perbedaan level ekspresi $\operatorname{Sox} 9$ pada tahapan tersebut menunjukkan bahwa Sox9 memainkan peran yang penting dalam proses awal determinasi seks gonad Chelonia mydas.

Kata kunci : Sox9, Temperature-dependent Sex Determination (TSD), Thermosensitive period (TSP), Chelonia mydas.

\section{INCUBATION TEMPERATURE INFLUENCE EXPRESSION PATTERN OF SOX9 IN THE EARLY} STAGE OF GONADAL DEVELOPMENT OF Chelonia mydas EMBRYO
\end{abstract}

\begin{abstract}
One of the important factor that is seems to be involved in sex determination of TSD animal is Sox9. Sox9 has an important role in the molecular sex-determining cascade. When the level of Sox 9 protein reach the treshold, it could drive the bipotential gonad to a testis differentiation. The research is conducted to examine $\operatorname{Sox} 9$ expression level in the early stage of gonadal development of Chelonia mydas, a species with TSD. Eggs were incubated in FPT $\left(31 \pm 1^{\circ} \mathrm{C}\right)$ incubator to produce $100 \%$ of female embryo, and the remaining in MPT $\left(26 \pm 1^{\circ} \mathrm{C}\right)$ produce $100 \%$ of male embryo. The examination level expression of mRNA was performed since preTSP till the end of TSP period. Quantification of $S f 1$ level expression from adrenal-gonad-kidney (AGK) complex of embryonic stage 12, 14, 16 (pre TSP), 17, 19 dan 22 (TSP), incubated in FPT $\left(31 \pm 1^{\circ} \mathrm{C}\right)$ or MPT $\left(26 \pm 1^{\circ} \mathrm{C}\right)$ were performed using RT-PCR method. Level expression of housekeeping gene â-actin is used as a control. Amplification product was electrophorized on TAE-Agarose gel and then documenting by using digital camera. The density of each DNA band were examined by using ScionImage Software. The average of 10 scores for each band was convert into a line diagram. RT-PCR result showed that the incubation temperature influenced mRNA expression level of Sox9. Expression level of Sox 9 is higher in embryo which were incubated in MPT $\left(26 \pm 1^{\circ} \mathrm{C}\right)$ than in FPT $\left(31 \pm 1^{\circ} \mathrm{C}\right)$. Differential expression level of the gene appear from the middle of preTSP till the middle of TSP. The highest level of the difference appear soon before Thermosensitive Period. Differential expression of $\operatorname{Sox} 9$ during the stage showed that $\operatorname{Sox} 9$ has an important role during the early stage of sex determination gonad of Chelonia mydas.

Key words: Sox9, Temperature-dependent Sex Determination (TSD), Thermosensitive period (TSP), Chelonia mydas
\end{abstract}

\section{PENDAHULUAN}

Determinasi seks atau penentuan jenis kelamin sangat penting dalam kelangsungan hidup suatu spesies. Pada vertebarata dikenal 2 jenis mekanisme determinasi seks, yaitu GSD (Genotypic Sex Determination) dan ESD (Environmental Sex Determination). Pada GSD, seks ditentukan saat fertilisasi oleh gen yang terpaut pada kromosom seks, sedangkan seks hewan ESD ditentukan oleh faktor lingkungan [1]. Hewan ESD yang seksnya ditentukan oleh suhu dikenal sebagai hewan TSD (Tem- perature-dependent Sex Determination), dan sebagian besar hewan ESD termasuk dalam kelompok ini [2]

Berbeda dengan vertebrata amniota lainnya yang jenis kelaminnya ditentukan secara genetik pada saat fertilisasi, jenis kelamin anakan pada banyak spesies reptil ditentukan secara permanen oleh suhu inkubasi embrio [3]. Rasio seks anakan pada taksa tersebut dapat berubah drastis akibat pergeseran suhu inkubasi meskipun hanya sebesar $1^{\circ} \mathrm{C}$ saja [4]. Karena rasio seks merupakan salah satu parameter demografik yang penting untuk viabilitas populasi, maka pemahaman yang lebih baik terhadap peran 
lingkungan dalam mempengaruhi rasio seks jelas sangat dibutuhkan [5].

Penelitian-penelitian untuk mencari penentu utama arah perkembangan gonad hewan TSD telah banyak dilakukan terutama pada periode termosensitif (TSP, thermosensitive period)) karena suhu inkubasi pada periode tersebut terbukti sangat mempengaruhi arah perkembangan gonad. Bila perlakuan suhu diberikan setelah TSP berlalu maka arah determinasi dan diferensiasi gonad tidak terpengaruh. Meskipun demikian gen/gen-gen yang menjadi penentu utama arah perkembangan gonad hewan TSD hingga saat ini belum diketahui. Akibat perbedaan suhu inkubasi, gen/gen-gen tersebut diduga telah terekspresi berbeda pada jaringan gonad dan sekitarnya sebelum embrio memasuki periode TSP. Perbedaan ekspresi gen-gen pada periode pra TSP ini yang diduga berperan menginisiasi perbedaan ekspresi gen-gen lain pada gonad tahap perkembangan selanjutnya.

Salah satu gen yang diduga memiliki peran penting dalam proses determinasi seks vertebrata adalah Sox9. Pada mencit protein ini dibutuhkan dalam jumlah yang cukup agar gonad indiferen berkembang menjadi testis [6]. Pada manusia dan mencit, Sox9 berinteraksi langsung dengan Sf1 untuk meningkatkan level ekspresi $A M H$ [7]. $A M H$ adalah anggota dari superfamili TGF-1 yang merupakan faktor pertama yang disekresikan oleh sel-sel Sertoli testis yang telah terdiferensiasi yang menyebabkan terjadinya regresi duktus Müller bakal uterus, cervix, dan tuba Fallopii [8]. Hubungan pengaturan ekspresi antara Sox 9 dan $A M H$ pada kelompok mammalia tampaknya tidak sama dengan hewan-hewan pada kelompok lain. Pada ayam yang GSD misalnya, perbedaan level ekspresi $A M H$ justru terjadi sebelum level ekspresi Sox 9 berbeda. Keterkaitan antar kedua gen tersebut belum diketahui dengan pasti [9]. Pola ekspresi tersebut mirip dengan pola ekspresi gen yang sama pada spesies TSD Alligator missisipiensis [10].

Pada spesies TSD lain seperti Eublepharis macularius dan Lepidochelys olivaceae perbedaan level ekspresi Sox9 pada suhu inkubasi yang berbeda tidak terlihat hingga TSP akhir [11]. Pada Trachemys scripta, level ekspresi $A M H$ tampak jelas lebih tinggi pada suhu maskulinisasi pada periode TSP tengah [12], meskipun [13] menemukan perbedaan tersebut terlihat justru setelah TSP berlalu. Pada penelitian lain, level ekspresi Sox 9 tampak tidak berbeda pada suhu inkubasi yang berbeda [14]. Dengan demikian penelitian pola ekspresi Sox 9 pada spesies TSD yang berbeda menarik untuk dilakukan dalam rangka lebih memahami mekanisme molekuler yang mungkin terjadi pada proses awal determinasi seks, khususnya spesies TSD dengan menggunakan Chelonia mydas sebagai hewan percobaan. Disamping itu hasil ddRT-PCR kompleks adrenal-gonad-ginjal Chelonia mydas yang dilakukan oleh [15] menunjukkan bahwa Sox 9 merupakan salah satu gen terduga yang menunjukkan perbedaan level ekspresi pada kompleks adrenal-gonadginjal Chelonia mydas yang langsung atau tidak langsung disebabkan oleh perlakuan suhu. Adanya perbedaan level ekspresi dari gen terduga ini telah terlihat sebelum embrio memasuki periode TSP sehingga verifikasi perbedaan level ekspresi gen tersebut perlu dilakukan.

\section{BAHAN DAN METODE \\ 2.1 Embrio Chelonia mydas}

Jaringan kompleks adrenal-gonad-ginjal yang menjadi bahan utama penelitian ini diisolasi dari embrio Chelonia mydas yang diinkubasi pada suhu tertentu. Telurtelur sumber adrenal-gonad-ginjal ini diperoleh dari telur yang baru dioviposisikan di lokasi peteluran penyu Pantai Pangumbahan Sukabumi Selatan, Jawa Barat. Telur-telur tersebut dibawa ke Laboratorium Analisis Struktur dan Perkembangan SITH, ITB, tempat pemberian perlakuan. Selama dalam perjalanan, telur-telur tersebut ditempatkan dalam kemasan khusus (carrier box) yang berisi pasir laut lembab untuk mempertahankan kelembaban telur sepanjang perjalanan. Telur-telur selanjutnya dipindahkan ke dalam baskom plastik berisi pasir laut basah hingga telur-telur tertimbun didalamnya.

Telur-telur diinkubasi di dalam inkubator (Blue M) pada suhu $31^{\circ} \mathrm{C} \pm 1{ }^{\circ} \mathrm{C}$ (suhu feminisasi, SF), atau disimpan di dalam ruang berpendingin suhu $26^{\circ} \mathrm{C} \pm 1^{\circ} \mathrm{C}$ (suhu maskulinisasi, SM). Pasir laut disiram dengan air ledeng setiap 2 atau 3 hari sekali agar telur tidak kering selama proses inkubasi berlangsung.

\subsection{Isolasi Gonad}

Kompleks adrenal-gonad-ginjal diisolasi dari embrio tahap perkembangan 12, 14, 16 (tahap pra TSP), 17, 19 dan 22 (tahap TSP). Tahapan perkembangan embrio ditentukan menurut [16]. Embrio yang diinkubasi pada suhu feminisasi hingga tahap 12 disebut SF12, sedangkan embrio yang diinkubasi pada suhu maskulinisasi hingga tahap 12 disebut SM12. Embrio yang telah mencapai tahap perkembangan yang telah ditentukan selanjutnya didekapitasi. Sebanyak $20 \mathrm{mg}$ - $30 \mathrm{mg}$ kompleks adrenal-gonad-ginjal yang diisolasi dari 5 - 12 ekor embrio (tergantung tahapan perkembangan embrio) kemudian dimasukkan ke dalam PBS dingin. Setelah ditimbang dengan menggunakan neraca analitik (Sartorius BF121S), kompleks organ-organ tersebut dipindahkan ke dalam cryotube dan disimpan dalam nitrogen cair pada suhu $-196^{\circ} \mathrm{C}$.

\subsection{Ekstraksi RNA, Pengukuran Kuantitas dan Kualitas RNA Total}

RNA total dari kompleks adrenal-gonad-ginjal diekstraksi menggunakan RNeasy Mini Kit (Qiagen). Konsentrasi RNA total diukur dengan menggunakan spektrofotometer (Ultraspec 2000, Pharmacia, Biotech ${ }^{\circledR}$ ) dengan mengukur absorbansi RNA terlarut pada panjang gelombang $260 \mathrm{~nm}\left(\mathrm{~A}_{260}\right)$. Nilai absorbansi sebesar satu (1) pada panjang gelombang $260 \mathrm{~nm}$ sebanding dengan $40 \mu \mathrm{g}$ RNA per $\mathrm{ml}\left(\mathrm{A}_{260}=1 \pm 40 \mu \mathrm{g} / \mathrm{ml}\right)$ (Davis dkk., 1994). Kemurnian RNA total ditentukan dengan menghitung rasio absorbansi UV pada panjang gelombang $260 \mathrm{~nm}\left(\mathrm{~A}_{260}\right)$ dan $280 \mathrm{~nm}\left(\mathrm{~A}_{280}\right)$, sedangkan kualitas RNA diamati dengan melakukan elektroforesis pada gel agarosa $1 \%$ yang mengandung etidium bromida dalam larutan bufer elektroforesis 1X BBE (Borate Boric EDTA). Adanya larik $18 \mathrm{~S}$ rRNA dan $28 \mathrm{~S}$ rRNA pada gel elektroforesis menunjukkan bahwa RNA total yang telah diisolasi tidak terdegradasi dan dapat digunakan dalam RT-PCR. 


\subsection{RT-PCR dan Elektroforesis}

RNA total yang diperoleh pada tahap sebelumnya selanjutnya disintesis menjadi cDNA (complementary $D N A)$ dengan proses reverse-transcription $(R T)$ menggunakan Superscript ${ }^{\mathbb{B}}$ III First-Strand Synthesis System for RT PCR (Invitrogen) dengan Random Hexamer primers. Fragmen cDNA hasil $R T$ selanjutnya diamplifikasi dengan campuran reaksi yang mengandung 1,25 unit Taq DNA Polymerase (BioLabs), 0,5 $\mu \mathrm{M}$ forward primer 5'AGTGGCAGC TACGGAATCA3' dan 0,5 $\mu$ M reverse primer 5'GCTGTAATGGCTCGGACTG3' (Invitrogen). $P C R$ dilakukan pada suhu denaturasi awal $95^{\circ} \mathrm{C}$ selama 10 menit, kemudian dilanjutkan dengan amplifikasi sebanyak 32 siklus pada suhu denaturasi $95^{\circ} \mathrm{C}$ selama 30 detik, suhu annealing $55^{\circ} \mathrm{C}$ selama 1 menit, dan suhu pemanjangan $72^{\circ} \mathrm{C}$ selama 1 menit. Pemanjangan akhir dilakukan pada suhu $72^{\circ} \mathrm{C}$ selama 7 menit. Sebagai kontrol digunakan housekeeping gene â-actin yang diamplifikasi dengan pasangan primer 5'GCCAACAGAGAGAAGATGAC3' (forward primer) dan 5'TCTTCATGAGGTAGTCCGTC-3' (reverse primer) (Invitrogen). Hasil amplifikasi fragmen target dan housekeeping gene â-actin dielektroforesis bersama $D N A$ ladder $100 \mathrm{bp}$ (Invitrogen) pada gel TAE-agarosa 2\%. Jumlah relative amplicon pada setiap larik DNA yang terbentuk ditentukan dengan menggunakan software Scion Image. Nilai densitas setiap larik ditentukan dari rata-rata 10 kali bacaan. Level ekspresi $S f 1$ ditentukan dengan menghitung rasio nilai rata-rata hasil Scion Image larik DNA Sf1 terhadap nilai rata-rata hasil Scion Image larik DNA â-actin pada tahap perkembangan embrio dan perlakuan yang sama. Nilai-nilai tersebut kemudian dikonversi ke dalam bentuk grafik garis.

\section{HASIL PENELITIAN}

Dalam penelitian ini telah dilakukan pengamatan level ekspresi gen Sox9 pada level RNA. Reverse transkripsi dan $P C R$ dilakukan pada seluruh sampel untuk mengamati pola ekspresi gen ini dengan menggunakan primer spesifik yang didesain untuk mengamplifikasi fragmen gen Sox 9 (Gambar 1B), dan sebagai kontrol internal dilakukan pula pengamatan terhadap level ekspresi frgamen gen $\hat{a}$-actin (Gambar 3.A).
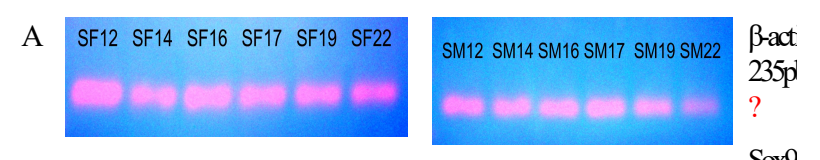

B
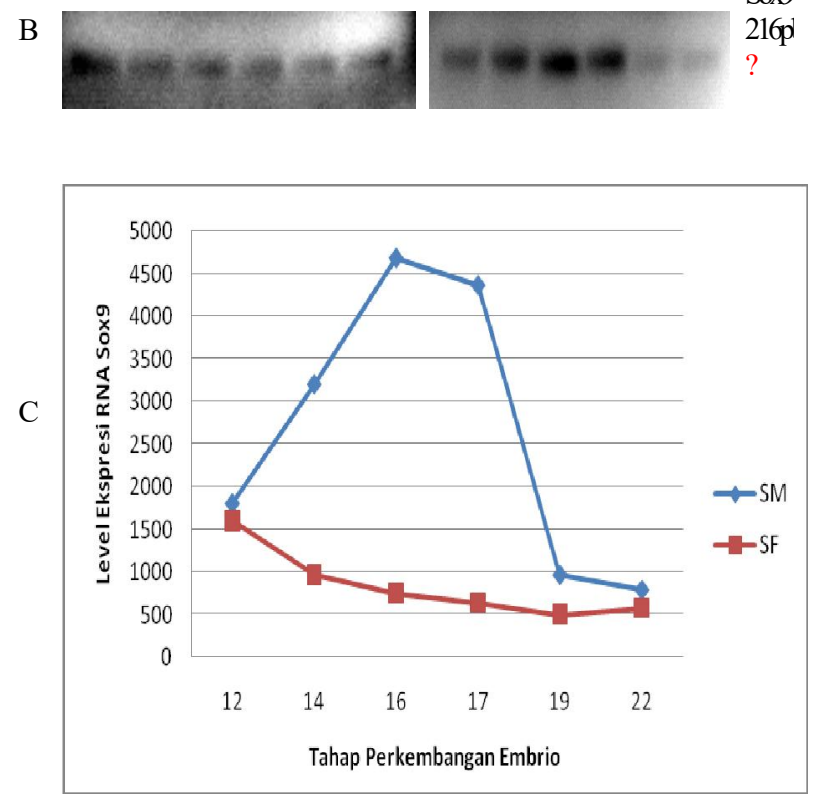

Gambar 3. Elektroferogram hasil RT-PCR $S 0 x 9$ (A) dan â-actin (B), serta grafik level ekspresi Sox9 hasil scion image (C). SF (suhu feminisasi); SM (suhu maskulinisasi); SF 12 (Hasil amplifikasi RNA kompleks adrenal-gonadginjal Chelonia mydas yang diinkubasi pada suhu feminisasi hingga tahap 12); SM12 (Hasil amplifikasi RNA kompleks adrenal-gonad-ginjal Chelonia mydas yang diinkubasi pada suhu maskulinisasi hingga tahap 12).

Hasil pengamatan eskpresi gen Sox9 pada level RNA (Gambar IC) menunjukkan adanya perbedaan pola antarkelompok perlakuan. Level ekspresi mRNA Sox 9 kompleks adrenal-gonad-ginjal dari embrio yang diinkubasi pada suhu jantan (SM) terdeteksi lebih tinggi dibandingkan dengan embrio yang diinkubasi pada suhu betina (SF). Perbedaan tersebut tampak jelas teramati sejak embrio tahap 14 (pra TSP tengah) hingga embrio tahap 19 (TSP tengah). Perbedaan terbesar terlihat pada embrio tahap 16 yang merupakan tahap menjelang embrio memasuki TSP. Pada TSP akhir (embrio tahap 22) level ekspresi gen ini hampir tidak berbeda pada suhu inkubasi yang berbeda.

\section{PEMBAHASAN}

Pada Chelonia mydas, suhu diduga menjadi inisiator yang mengarahkan gonad berkembang menjadi testis atau ovarium. Hasil penelitian ini menunjukkan bahwa suhu inkubasi mempengaruhi pola ekspresi Sox9. Level ekspresi gen ini terlihat lebih tinggi pada embrio yang diinkubasi pada suhu maskulinisasi (SM) dibandingkan dengan embrio yang diinkubasi pada suhu feminisasi (SF). Lebih tingginya level ekspresi Sox9 pada SM diduga disebabkan oleh tingginya level ekspresi $S f 1$. [17] menemukan level ekspresi Sfl lebih tinggi pada embrio Chelonia mydas yang diinkubasi pada suhu maskulinisasi sejak embrio tahap 12. Dengan demikian peningkatan level ekspresi Sox 9 yang terlihat pada embrio 
tahap 14 diduga merupakan akibat dari terjadinya peningkatan level ekspresi $S f l$ yang terbentuk pada embrio tahap sebelumnya. Inkubasi embrio pada suhu rendah (SM) diduga mengaktivasi molekul target tertentu (yang berbeda dari molekul yang teraktivasi pada SF) untuk meningkatkan produksi Sf1 sehingga kadar Sf1 pada jaringan gonad dan sekitarnya mencapai batas ambang tertentu yang dibutuhkan untuk meningkatkan level eskpresi Sox 9 dan $A M H$. Ekspresi Sox9 pada sel Sertoli gonad yang telah terdiferensiasi berperan mengaktivasi ekspresi Amh [18] yang dibutuhkan untuk meregresi duktus Müller [19]. Protein AMH selanjutnya juga dapat berperan menekan ekspresi gen-gen aromatase [20] sehingga gonad bipotensial memasuki jalur determinasi testis. Peningkatan level ekspresi Sox9 juga diduga berperan menekan level ekspresi aromatase. [21] menemukan terjadinya penurunan level protein aromatase yang terdeteksi pada gonad embrio yang diinkubasi pada SM. Hal tersebut diduga akibat meningkatnya level ekspresi Sfl yang selanjutnya berdampak pada meningkatnya level ekspresi Sox 9 dan $A M H$. Protein AMH selanjutnya dapat berperan dalam menekan ekspresi gen-gen aromatase [20]. Data-data tersebut menunjukkan bahwa ekspresi $\operatorname{Sox} 9$ dan $S f 1$ memiliki peran yang sangat penting dalam tahap awal perkembangan gonad spesies ini.

Suhu tinggi (SF) kemungkinan berperan mengaktivasi molekul target tertentu untuk menekan produksi Sf1 yang selanjutnya mengarahkan Sf1 untuk berikatan dengan Dax1. Sf1 bersama Dax1 mampu berperan dalam menghambat fungsi $\mathrm{Wt} 1$ dan sekaligus menghambat transkripsi gen Sox 9 dan $A M H$. Kondisi ini mampu mengarahkan gonad bipontesial mengikuti jalur determinasi ovarium.

\section{KESIMPULAN}

Pola ekspresi Sox9 pada tahap awal perkembangan gonad dipengaruhi oleh suhu inkubasi. Embrio yang diinkubasi pada suhu rendah (SM) menunjukkan level ekspresi Sox9 yang lebih tinggi dibandingkan dengan level eskpresi Sox9 embrio yang diinkubasi pada suhu tinggi (SF). Hal tersebut terlihat sejak embrio memasuki tahap sangat awal pembentukan gonad yaitu pra TSP, hingga embrio tahap TSP tengah. Hal ini menunjukkan bahwa Sox9 memiliki peran yang penting dalam proses determinasi seks gonad embrio Chelonia mydas, terutama untuk mengarahkan perkembangan gonad bipotensial menjadi gonad jantan.

\section{DAFTAR PUSTAKA}

[1] Bull, J.J. (1983): Evolution of sex determining mechanisms, Menlo Park, California, Bejamin/ Cummings Publishing Company Inc 316p

[2] Valenzuela N., Adams. C., Janzen F. J., 2003. Pattern does not equal process: exactly when is sex environtmentally determined? The American Naturalist 161: 676-683

[3] Bull, J. J. (1980): Sex determination in reptiles, Q. Rev. Biol., 55, 3-21

[4] Paukstis, G. L., dan Janzen, F. J. (1990): Sex determination in reptiles summary of effects of constant temperatures of incubation on sex ratios of offspring. Smithson. Herpetol. Inform.Serv, 83, 1-28.

[5] Stelkens, R.B. dan Wedekind, C. (2010): Enviromental sex reversal, Trojan sex genes, and sex ratio adjustment: condition and population consequences, Mol. Ecol., 19, 627-646.

[6] Vidal VPI, Chaboissier M-C, de Rooij DG, Schedl A. 2001. Sox9 induces testis development in XX transgenic mice. Nat Genet 28:216-217.

[7] de Santa Barbara P, Bonneaud N, Boizet B, Desclozeaux M, Moniot B, Sudbeck P, Scherer G, Poulat G, Berta P. 1998. Direct interaction of SRY-related protein SOX9 and steroidogenic factor 1 regulates transcription of the human anti-Mu“ llerian hormone gene. Mol Cell Biol 18:6653-6665.

[8] Behringer RR, Cate RL, Froelick GJ, Palmiter RD, Brinster RL. (1990): Abnormal sexual development in transgenic mice chronically expressing Mullerian inhibiting substance. Nature 345:167-170

[9] Oreal E, Pieau C, Mattei M-G, Josso N, Picard J-Y, Carre-Eusebe D, Magre S. 1998. Early expression of $\mathrm{AMH}$ in chicken embryonic gonads precedes testicular SOX9 expression. Dev Dyn 212:522-532.

[10] Western, P.S., Harry, J.L., Marshall, Graves, J.A., Sinclair, A.H. (1999): Temperature-dependent sex determination in the American alligator: AMH precedes SOX9 expression. Dev. Dynam

[11]Moreno-Mendoza, N., Harley, V.R. dan Merchant-Larios, H. (1999): Differential expression of SOX9 in gonad of sea turtle Lepidochelys olivacea at male- or femalepromoting temperatures, Journal of Experimental Zoology, 284, 705-710.

[12] Takada S, DiNapoli L, Capel B, Koopman P. 2004. Sox 8 is expressed at similar levels in gonads of both sexes during the sex determining period in turtles. Dev Dyn 231:387-395.

[13] Spotila, L., Spotila, J.R., Hall, S.E. (1998): Sequence and expression analysis of $W T-1$ and $S O X 9$ in the red-eared slider turtle, Trachemys scripta.J. Exp. Zool. 281, 417-427.

[14] Kettlewell JR, Raymond CS, Zarkower D. 2000. Temperature-dependent expression of turtle Dmrt1 prior to sexual differentiation. Genesis 26:174-178.

[15] Bahri, Syamsul (2009) Pola ekspresi gen kandidat penentu seks gonad Chelonia mydas sebelum periode termosensitif. Laporan Penelitian Hibah Doktor. ITB, Bandung

[16] Greenbaum, E. (2002): A standardized series of embryonic stages for the emydid turtle Trachemys scripta, Can.J. Zool., 80, 1350-1370

[17] Bahri, Syamsul (2011) Pola ekspresi steroidogenic factor $1(\mathrm{Sfl})$ pada tahap awal perkembangan gonad embrio Chelonia mydas. Biologi Tropis $12: 1$ 
Suhu Inkubasi Mempengaruhi Level Ekspresi SOX9 Pada Tahap Awal Perkembangan Gonad .....(Syamsul Bahri)

[18] Kent, J., Wheatley, S. C., Andrews, J. E., Sinclair, A. H., dan Koopman, P. (1996): A male-specific role for $S O X 9$ in vertebrate sex determination, Development, 122, 2813-2822

[19] Hacker, A., Capel, B., Goodfellow, P., dan LovellBadge, R. (1995): Expression of Sry, the mouse sex determining gene, Development, 121, $1603-1614$

[20] Pieau, C., Dorizzi, M. dan Richard-Mercier, N. (1999): Temperature dependent sex determination and gonadal differentiation in reptiles, Cell.Molec.LifeScie., 55, 887-900

[21] Equilibrina, I. (2007): Kehadiran aromatase pada gonad embrio penyu hijau (Chelonia mydas) selama periode termosensitif. Skripsi Sarjana Biologi. ITB, Bandung 